\title{
Elections to the Fellowship, 1990
}

The Members listed below have been elected as Fellows of the College by the Court of Electors:

Dr A. M. H. Al-Jadiry, Dr J. V. Basson, Dr R. I. Bearcroft, Dr H. L. Behr, Dr M. K. G. Bhakta, Dr J. R. Bird, Dr B. Bodhinayake, Dr W. R. Breakey, Dr R. G. Congdon, Dr W. M. Cottrell, Dr S. Craske, Dr J. M. R. Damas-Mora, Dr S. Das-Gupta, Dr M. S. Davies, Dr J. Eastwood, Dr P. R. Evans, Dr L. H. Fagin, Dr P. T. P. Fahy, Dr I. N. Ferrier, Dr P. F. Finlayson, Dr C. P. L. Freeman, Dr T. Ganesvaran, Dr J. D. Gomersall, Dr I. M. Goodyer, Dr H. A. Hafeiz, Dr B. Hale, Dr T. W. Harding, Dr Q. Harris, Dr K. E. Hawton, Dr U. H. Ihezue, Dr T. C. Jerram, Dr M. Johnston, Dr J. Lambourn, Dr M. R. Lowe, Dr A. L. MacNeill, Dr M. R. Malcolm, Professor P. McGuffin, Dr W. E. Mickleburgh, Dr H. R. Millar, Dr P. A. Murray, Dr M. Norman-Nott, Dr M. R. Oates, Dr M. R. O'Connell, Dr F. P. O'Donoghue,
Dr M. Peet, Dr D. W. Pierce, Dr I. M. Pullen, Professor S. L. Purshotamdas, Dr I. B. Raafat, Dr D. W. Rankin, Dr J. P. Roberts, Dr N. Savla, Dr Z. A. Sayed, Dr O. E. P. Shanks, Dr C. C. Sherry, Dr J. H. W. Short, Dr S. Soni, Dr D. S. Stephen, Dr A. R. Stewart, Dr G. D. Stewart, Dr J. Strum, Dr R. Thavasothy, Dr R. J. Turner, Professor J. L. Vazquez-Barquero, Dr L. J. Whalley, Dr R. J. W. Williams, Dr A. H. Wilson, Dr C. H. Wilson.

\section{Elections to the Membership under Bye-Law III 2 ii}

The following have been elected as Members of the College by the Court of Electors:

Dr E. W. Birchall, Dr N. Bouras, Dr D. F. Broderick, Dr T-A Cheng, Dr R. Hinshelwood, Dr M. R. Keen, Dr D. H. Montgomery.

\section{Obituary}

Editor: Henry R. Rollin

James A. S. Muluigan, formerly Resident Medical Superintendent and Consultant Psychiatrist, St Luke's Hospital, Armagh

Dr Jim Mulligan died on 30 November 1989 at home in retirement in Belfast. The only son of Reverend and Mrs James Mulligan, he had grown up in the manse at Jerritspass, Newry. Born on 26 September 1913 , his secondary education had been in the Royal School, Dungannon, from which he went to Queen's University, Belfast. He graduated MB, BCh, BAO in 1936 and took up House Officer posts and became casualty Officer at the Royal Victoria Hospital, Belfast.

He then joined the staff of Holywell Hospital, Antrim, the mental hospital for Co. Antrim. Shortly after the outbreak of the war he volunteered for army service and became a Captain in the RAMC. Three days after his marriage to Prudence, in October 1940, he sailed to North Africa. The whole regiment was captured by Rommel a few weeks after arrival with the result that he spent almost the entire war as a prisoner of war. His diaries, kept meticulously, are a tribute to his recording discipline and skill, despite the extreme hardship he endured at Stalagate camp in Germany for the final year, as opposed, that is, to the more relaxed atmosphere of the earlier four years as a POW doctor in Lucia, North Italy.

He returned home in a rather poor physical state and set to work writing his MD thesis on the management and treatment of long stay patients-largely based on what he had experienced in his years of 